\title{
PENGARUH GAYA KEPEMIMPINAN DAN MOTIVASI KERJA TERHADAP KINERJA PEGAWAI
}

(Studi Kausal pada Dinas Pembinaan Mental TNI-AD di Jakarta)

\begin{abstract}
MA'SUM AMIN*
Abstract: The objective of the research is to determine the effect of leadership style and work motivation on employee performance. The research was conducted at Dinas Pembinaan Mental TNI-AD in Jakarta, 2010 with $n=66$ selected randomly. The result of research are as follows: (1) there is significant direct effect of leadership style on employee performance at Dinas Pembinaan Mental TNI-AD in Jakarta; (2) there is significant direct effect of work motivation on empoyee performance at Dinas Pembinaan Mental TNI-AD in Jakarta; and (3) there is significant direct effect of leadership style on employee's work motivation at Dinas Pembinaan Mental TNI$A D$ in Jakarta. Based on the result of research, the employee performace at Dinas Pembinaan Mental TNI-AD in Jakarta could be enhanced by increasing leadership style and work motivation as significant determinant factors.
\end{abstract}

Keywords: leadership style, work motivation, and performance.

\section{PENDAHULUAN}

Kepemimpinan dalam organisasi merupakan bagian yang sangat penting dalam mengarahkan dan memahami perilaku pegawai serta memotivasinya guna mewujutkan kinerja organisasi yang optimal dalam rangka mencapai tujuan organisasi. Dalam mencapai tujuan organisasi banyak faktor yang mempengaruhi di antaranya kualitas sumber daya manusia atau pegawai, metode kerja, lingkungan kerja dan fasilitasfasilitas penunjang lainnya yang dapat menentukan kualitas kerja pegawai.

Kinerja pegawai perlu mendapat perhatian utama guna mencapai efektif dan Efesiensi organisasi. Kinerja pegawai yang optimal diperlukan pemahaman terhadap perilaku individu seseorang yang akan berdampak kepada kualitas kinerja pegawai, oleh karena itu di perlukan kemampuan pemimpindalam mengarahkan terhadap pegawai dan memahami perilaku serta motivasi kerja pegawai dalam menjalankan tugas dan pekerjaanya.

Gaya kepemimpinan merupakan pola prilaku yang dipilih oleh pemimpin dalam proses mengerahkan dan mempengaruhi pegawai. Didasari bahwa tidak ada satupun gaya kepemimpinan yang paling efektif dapat di terapkan dalam kepemimpinan seseorang karena kepemimpinan yang efektif sangat tergantung pada kemampuan seseorang pemimpin dalam memahami individunya serta kemampuan meyakinkan dirinya dengan situasi dan kondisi organisasi. penentuan gaya kepemimpinan yang tepat sesuai dengan situasi dan kondisi organisasi akan meningkatkan kerja pegawai mencapai pruduktivitas yang tinggi.

Disbintalad merupakan Unit Organisasi TNI-AD yang menyelenggarakan Pembinaan Mental bagi Prajurit dan PNS TNI-AD. Disbintalad menjalankan fungsi utama berupa bin fungsi yang meliputi segala usaha, pekerjaan dan kegiatan yang bekenaan dengan pembinaan organisasi dan kemampuan Bintalwan, peraturan dan petunjuk, kurikulumdan bahan pengajaran/penataran, pelatihan teknis bintal, litbang

* Kadisbintal Angkatan Darat 
pembinaan rohani, idiologi dan kejuangan. didalam kemiliteran dikenal dengan Kepemimpinan Garis Komando yaitu loyalitas yang tegak lurus dari atas kebawah atau sebaliknya. loyalitas ini akan terwujud manakala didukung oleh karakter kepemimpinan yang kuat dengan menerapkan gaya kepemimpinan yang tepat dan dapat memotivasi pegawai guna menungkatkan kinerjanya. Salah satu permasalahan penting bagi pemimpin ialah bagaimana memberikan motivasi kepada pegawai untuk melakukan pekerjaan dengan baik guna mencapai kinerja yang optimal.

Kinerja Pegawai. Porter dan Lawler dalam Wibowo berpendapat bahwa kinerja merupakan fungsi dari keinginan melakukan pemahaman yang jelas atas apa yang di kerjakan dan bagaimana mengerjakannya (2009:100). Kanfer dalam George dan Jones, menyatakan bahwa kinerja adalah: "Performance is an evaluation of the results of a person behaviour. It involves determining how well or poorly a person has accomplished a task or done a job." ( Kinerja sebagai suatu penilaian atas hasil perilaku individu yang didalamnya juga termasuk bagaimana pengukuran baik dan buruknya tindakan individu tersebut dalam menyelesaikan tugas atau pekerjaannya). (2002:176). Ruki dalam Anwar prabu mengatakan: "Performance is defined as record of outcomes produced on specified job function or activity during a specified time period". ( kinerja adalah catatan tentang hasil-hasil dari fungsi, aktivitas atau kegiatan tertentu selama kurun waktu tertentu pula). (2001:15) Posner dan Schmidt dalam robbin mengatakan: "performance is the degree to which the individual believes that performing at a particular level will lead to attainment of desired outcome" ( kinerja adalah tingkat keyakinan seseorang bahwa perbuatan pada suatu tingkat tertentu akan mengarah kepada pencapaian hasil yang diinginkan). (2003:52).Sedangkan Newstrom dan Davis : Kinerja pada dasarnya tidak berdiri sendiri, tetapi terkait dengan manejemen lainnya. (2002:103-104)

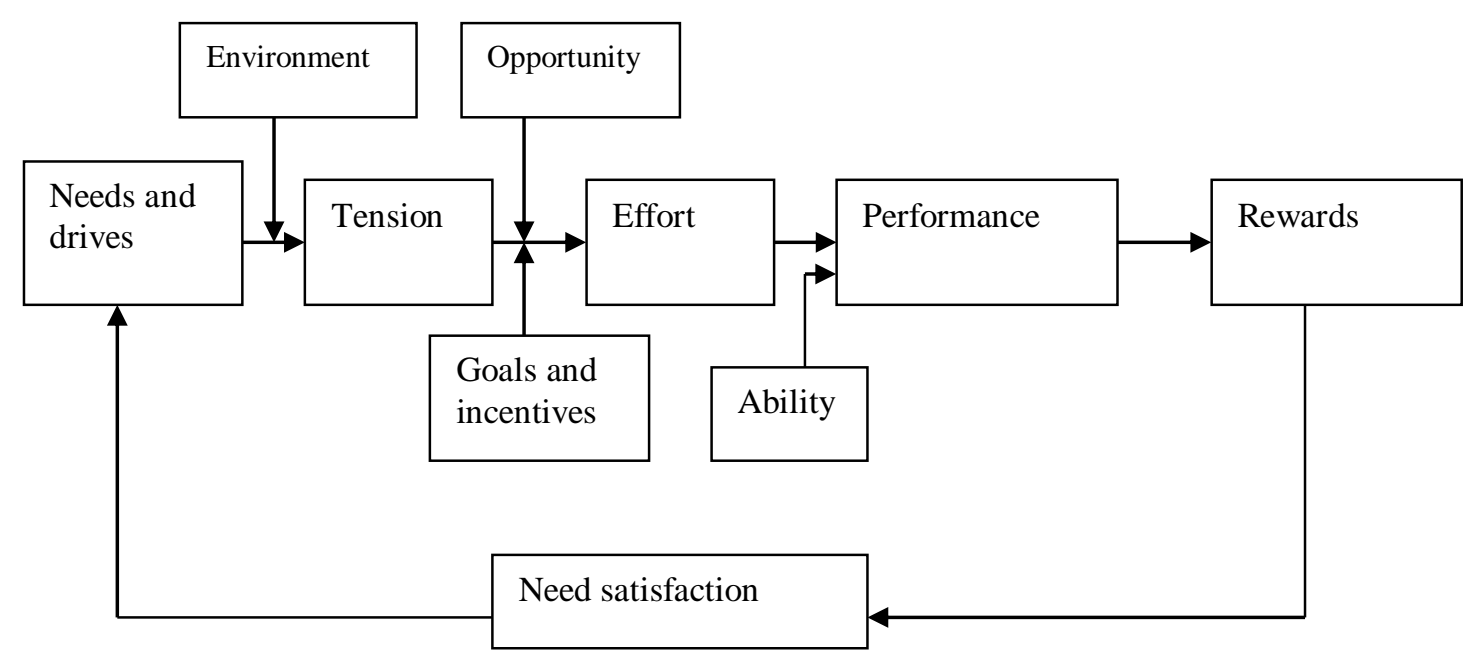

Model theory kinerja didasarkan pada Integrative Model of Organization Behavior dari Collquitt (2009:35) 


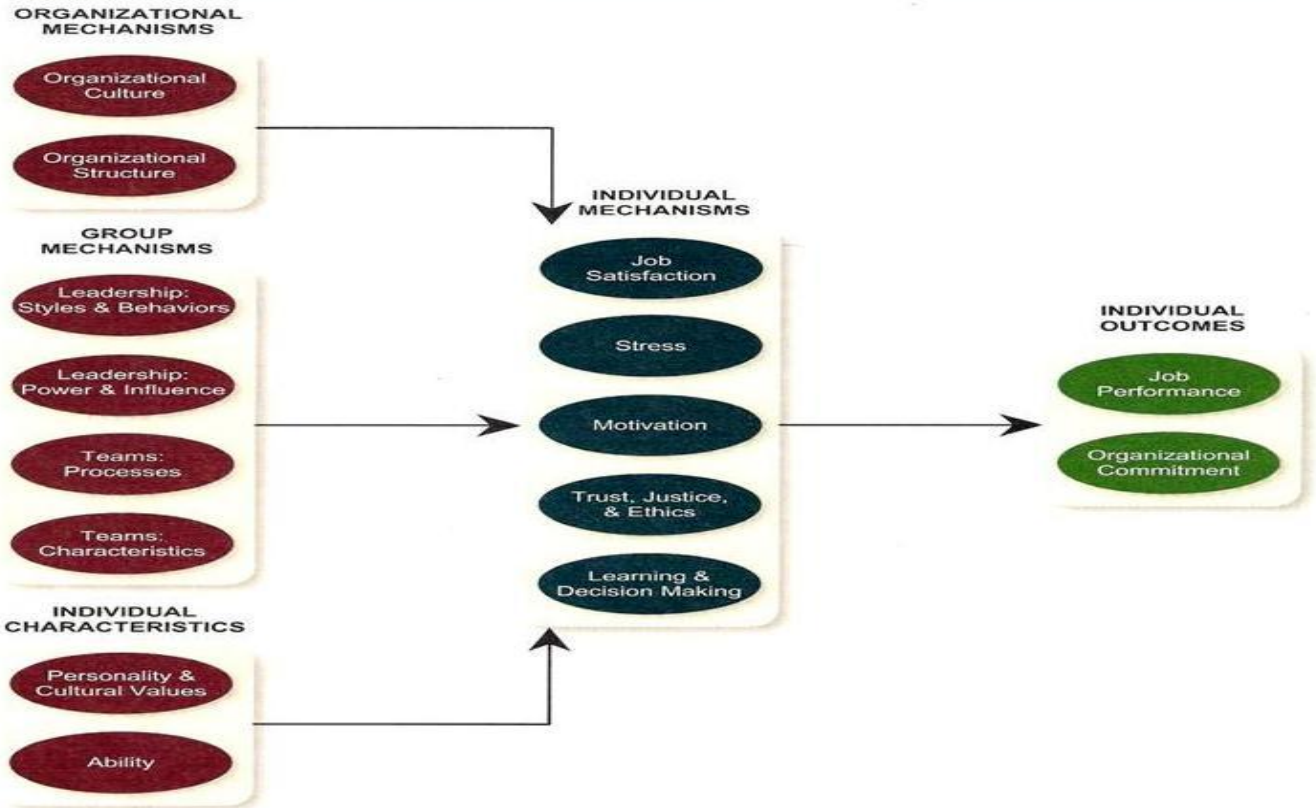

Ivancevich memberikan ketentuan tentang kinerja:

"job performance may be viewed as a function of the capacity to perform, the opportunity to performance and the willingness to perform."

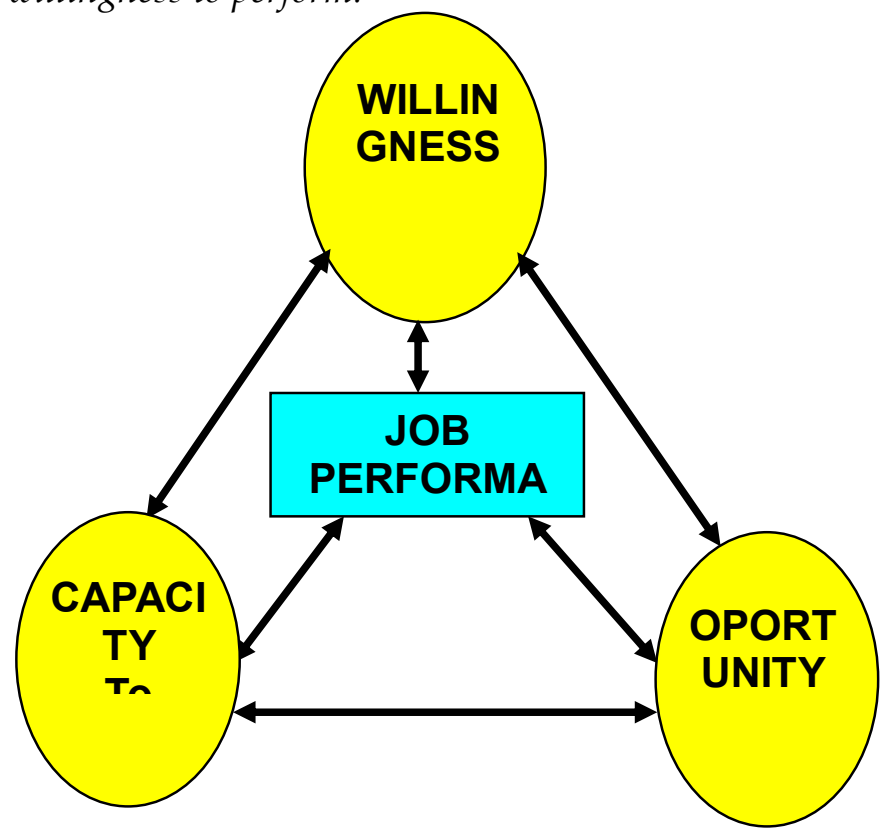

Dessler menyatakan 5 (lima) faktor penilaian kinerja yaitu: (1)Kualitas, (2) Kuantitas, (3) Supervisi, (4) Kehadiran, (5) Konservasi

Berdasarkan teori-teori diatas maka kinerja pegawai adalah penilaian hasil kerja secara kualitas dan kuantitas yang di capai oleh seorang pegawai dalam melaksanakan tugasnya sesuai dengan tanggung jawab yang diberikan kepadanya dan kehadiran yang dapat dihandalkan dan dipercaya serta pencapaian target pekerjaan. 
Motivasi Kerja. Dalam mencapai kinerja diperlukan adanya motivasi sebagai "intencity of person desirer to angage in some activity". (Intensitas hasrat seseorang untuk melakukan aktivitas).(2001:321). Wexley \& Yulk dalam As'ad memberikan batasan mengenai motivasi sebagai "the process by whic behavior is energized and directed." ( Motivasi merupakan hal yang melatar belakangi individu berberbuat untuk mencapai tujuan tertentu). (2008:45). Robbins mendefinisikan motivasi sebagai, "The Process by which a persons efforts are energized, directed and sustained attaining a goal." (Proses yang ikut menen-tukan intensitas, arah dan ketekunan individu dalam usaha mencapai sasaran). (2007:482). Chuck mendefinisikan motivasi sebagai, "is the set of forces that initiates, directs, and makes people persist in their effort to accomplish a goal." ( Sebuah upaya yang menginisiatifkan, mengarahkan dan membuat seseorang secara teguh/keras dalam usahanya mencapai tujuan). (2005:550). sedangkan menurut Gibson, et al motivasi didefinisikan sebagai, "...the concept we use when we describe the forces acting on or within an individual to initiate and direct behavior." (Sebuah konsep yang kita gunakan pada saat kita menggambarkan tindakan kekuatan/usaha pada atau di dalam diri seseorang untuk menginsiatifkan dan mengarahkan perilaku). (2006:132). McShane dan Von Glinow mendefinisikan motivasi sebagai, sebuah kekuatan yang ada di dalam diri seseorang yang berdampak pada arah (directions), intensitas (intensity) dan keteguhan (persistence) perilakunya (2005:140). menurut Herzberg dalam Timpe A Dale. Motivasi pegawai sangat erat kaitanya antara faktor higienis dan motivator (2002:320).

\begin{tabular}{|l|l|l|l|}
\hline \multicolumn{2}{|c|}{ FAKTOR PEGAWAI } & \multicolumn{2}{c|}{ FAKTOR MANAJEMEN } \\
\hline Higienis & Motivator & \multicolumn{1}{c|}{ Higienis } & \multicolumn{1}{c|}{ Motivator } \\
\hline Pengawasan & Pengakuan & Kehadiran & $\begin{array}{l}\text { Tingkat } \\
\text { pengawasan } \\
\text { yang } \\
\text { diperlukan }\end{array}$ \\
\hline Kondisi Kerja & $\begin{array}{l}\text { Tanggung } \\
\text { Jawab; } \\
\text { Tantangan }\end{array}$ & $\begin{array}{l}\text { Penerimaan } \\
\text { tugas pekerjaan }\end{array}$ & $\begin{array}{l}\text { Tanggung } \\
\text { Jawab }\end{array}$ \\
\hline Jaminan Pekerjaan & $\begin{array}{l}\text { Potensi } \\
\text { Pertumbuhan }\end{array}$ & $\begin{array}{l}\text { Penerimaan } \\
\text { manajemen; } \\
\text { Hubungan kerja } \\
\text { dengan pegawai } \\
\text { lain }\end{array}$ & $\begin{array}{l}\text { Kreativitas } \\
\text { sikap }\end{array}$ \\
\hline
\end{tabular}

Adam dan Donovan dalam Equity Theory bahwa motivasi sebagai persepsi keadilan. Partisipasi pegawai ditempat kerja adalah sebagai proses barter, pemberian kerja keras dan keahlian mengharapkan hasil kerja yang baik berupa gaji atau pengakuan.

Berdasarkan teori-teori diatas maka motivasi kerja adala dorongan atau keinginan yang timbul pada diri seseorang sadar atau tidak sadar untuk melakukan tindakan dengan tujuan tertentu atau usaha-usaha yang dapat menyebabkan seseorang atau sekelompok orang tertentu bergerak melakukan sesuatu karena keinginan mencapai tujuan yang dikehendakinya atau mendapatkan kepuasan atas perbuatannya. 
Gaya Kepemimpinan. Menurut Yukl, "Leadership is the process of influencing others to understand and agree about what need to be done and how to do it, and the process of facilitating individual and collective afforts to accomplish shared objetives." (Kepemimpinan adalah proses mempengaruhi orang lain untuk memahami dan setuju dengan apa yang perlu dilakukan dan bagaimana tugas itu dilakukan secara efektif dan proses untuk menfasilitasi upaya individu dan kolektif untuk mencapai tujuan bersama). (2010:26). Ivancevich mendefinisikan kepemimpinan sebagai, "Process of influencing other to facitate the attainment of organizationally relevan goal." (Proses mempengaruhi orang lain untuk memudahkan penerapan organisasi sesuai dengan tugasnya). (2008:437). Kepemimpinan merupakan bagian Integrital dalam manajemen yang harus dilakukan dalam rangka mempengaruhi orang lain atau bawahan untuk tidak melakukan hal-hal yang salah melainkan sebaliknya diarahkan untuk melakukan aktivitas yang mendukung tercapainya tujuan organisasi (devis; dan Newstrom, 2002:180).

Gaya Kepemimpinan merupakan sekumpulan ciri yang digunakan pemimpin untuk mempengaruhi bawahan agar sasaran organisasi dapat tercapai ( Timpe et al, 1992:143). Gaya kepemimpinan adalah pola perilaku dan strategi yang disukai dan sering ditetapkan oleh seorang pimpinan (Knezevich, 1984:337). Menurut Hersey \& Blanchard dalam Mosley pada dasarnya gaya kepemimpinan seseorang terbagi pada dua kecenderungan, yaitu berorientasi pada tugas (task behavior) dan berorientasi pada hubungan (relationship behavior) (2005:225). gaya kepemimpinan juga menunjukan secara langsung dan tidak langsung tentang keyakinan seorang pimpinan terhadap kemampuan bawahannya (Newstrom dan devis, 2002:181). Fieder dan Robin. menyebutkan bahwa kinerja yang efektif tergantung pada kesesuaian antara gaya pemimpin dan sejauh mana situasi memberikan kendali kepada pimpinan, selanjutnya Fieder menyebutkan bahwa salah satu faktor utama bagi pemimpin yang berhasil adalah gaya kepemimpinan dasar seseorang individu. (2007:p.58) Ada tiga faktor situasi kunci bagi kepemimpinan efektif; hubungan dengan anggota, struktur tugas dan kekuatan posisi. (2007:p.59). Menurut Blanchard dalam Mosley, gaya kepemimpinan yang efektif ditinjau dari tingkat kematangan bawahan tersebut Four Basic Leadership Style (1) Structuring selling, (2)Choashing telling, (3) Participasing dan Supporting, (4) Delegating (2005 : 225) Tingkat Kematangan Bawahan: (1) M1: Tindakan mampu dan tidak,(2) M2: Tidak mampu tapi mau, (3) M3: Mampu tetapi tidak mau, (4) M4: Mampu dan mau.

Berdasarkan teori-teori diatas maka: gaya kepemimpinan adalah suatu cara yang dipilih dan digunakan oleh pemimpin secara situasional dalam berinteraksi guna mengarahkan dan mempengaruhi bawahan/pengikut, yang diindikasikan dengan memberitahukan ( structuring-Aclling), membujuk (shelling-coaching), mengajak bawahan berperan serta(participating-suporting), dan melakukan pendelegasian (delegating). 


\section{METODE PENELITIAN}

Veriabel Penelitian

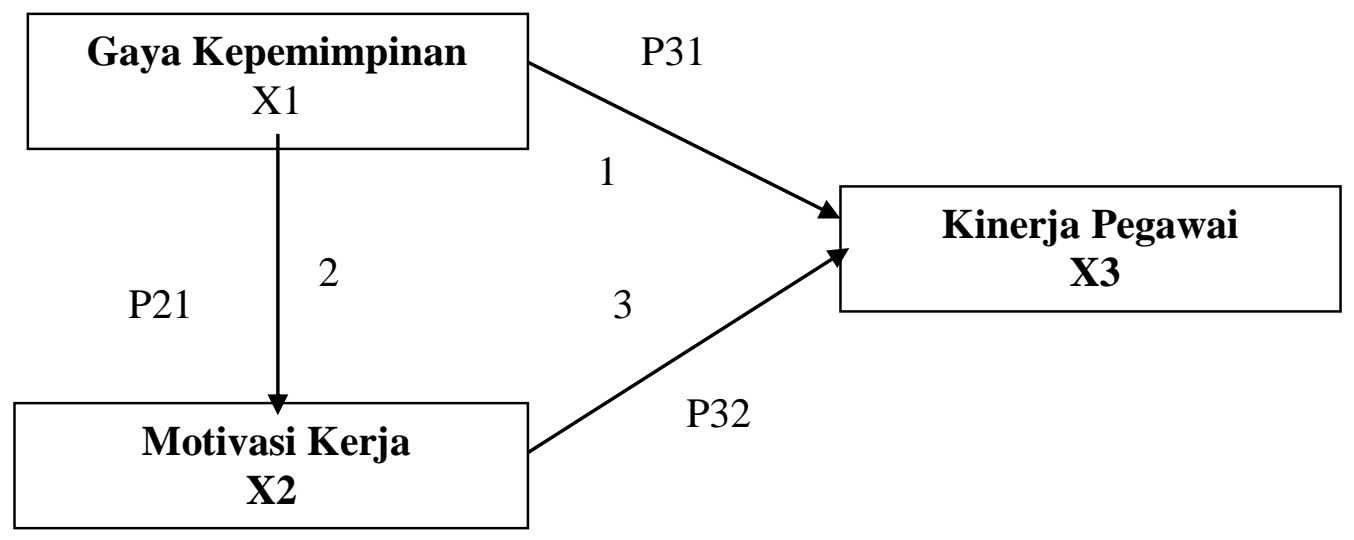

Gambar Model Hipotetik Penelitian

Sumber: Jason A. Colquitt; Jeffery A. LePine \& Michael J. Wesson, Organizational Behavior: Improving Performance and Commitment in the Workplace, (New York: McGraw Hill, 2009), p.35.

\section{Hipotesis Statistik}

1. Hipotesis $1 \quad \mathrm{H}_{0}: \mathrm{p}_{31} \leq 0$

$\mathrm{H}_{1}: \mathrm{p}_{31}>0$

2. Hipotesis $2 \quad \mathrm{H}_{0}: \mathrm{p}_{32} \leq 0$

$\mathrm{H}_{1}: \mathrm{p}_{32}>0$

3. Hipotesis $3 \quad \mathrm{H}_{0}: \mathrm{p}_{21} \leq 0$

$\mathrm{H}_{1}: \mathrm{p}_{21}>0$

\section{PEMBAHASAN HASIL PENELITIAN}

Hasil analisis dan pengujian hipotesis menunjukkan bahwa ketiga hipotesis yang diajukan dalam penelitian ini diterima dan teruji kebenarannya. Hal ini berarti terdapat pengaruh langsung Gaya Kepemimpinan terhadap Kinerja Pegawai (hipotesis 1), terdapat pengaruh langsung Motivasi Kerja terhadap Kinerja Pegawai (hipotesis 2), dan terdapat pengaruh langsung Gaya Kepemimpinan terhadap i Motivasi Kerja (hipotesis 3). Lebih rinci hasil analisis dan pengujian hipotesis tersebut dapat dijelaskan sebagai berikut ini.

\section{Pengaruh Gaya Kepemimpinan $\left(X_{1}\right)$ terhadap Kinerja Pegawai $\left(X_{3}\right)$}

Gaya Kepemimpinan terbukti mempunyai pengaruh langsung terhadap Kinerja Pegawai secara sangat signifikan dengan koefisien jalur $=0,483$. Terdapatnya pengaruh langsung tersebut terkandung makna bahwa makin baik Gaya Kepemimpinan maka akan meningkat pula Kinerja Pegawainya.

Kepemimpinan sebagai sebuah proses memberi arti (pengarahan yang berarti) terhadap usaha kolektif, dan yang mengakibatkan kesediaan untuk melakukan usaha 
yang diinginkan untuk mencapai sasaran. Kepemimpinan merupakan bagian integral dalam manajemen yang harus dilakukan dalam rangka mempengaruhi orang lain atau bawahan untuk tidak melakukan hal-hal yang salah melainkan sebaliknya diarahkan untuk melakukan aktivitas yang mendukung tercapainya tujuan organisasi. Dalam arti ini, gaya kepemimpinan seseorang jika dikaitkan dengan tercapainya tujuan organisasi ditandai dengan adanya kinerja pegawai suatu organisasi yang juga positif.

Robin mendefinisikan leadership as the ability to influence a group toward the achievement of a vision or set of goal. (Kepemimpinan adalah kemampuan mempengaruhi sebuah kelompok untuk mencapai suatu visi atau serangkaian tujuan tertentu). Dengan demikian, kepemimpinan merupakan kecakapan atau kemampuan seseorang untuk mengajak orang lain agar bersedia bekerja keras dalam mencapai tujuan organisasi yang telah ditetapkan. Kerja keras dan berhasil mencapai tujuan organisasi yang telah ditetapkan tidak lain adalah parameter dari keberhasilan suatu kinerja. Pengarahnya adalah pemimpin dengan segenap gaya kepemimpinannya. Hal tersebut sesuai dengan temuan dalam penelitian tesis ini yang menyatakan terdapat pengaruh langsung Gaya Kepemimpinan terhadap Kinerja Pegawai.

\section{Pengaruh Motivasi Kerja $\left(X_{2}\right)$ terhadap Kinerja Pegawai $\left(X_{3}\right)$}

Motivasi Kerja terbukti mempunyai pengaruh langsung terhadap Kinerja Pegawai secara sangat signifikan dengan koefisien jalur $=0,806$. Dengan kekuatan pengaruh seperti itu terkandung arti bahwa makin tinggi Motivasi Kerja, maka akan semakin tinggi Kinerja Pegawainya. Sementara itu, Mangkunegara berpendapat bahwa motivasi kerja merupakan kondisi atau energi yang menggerakkan diri karyawan yang terarah atau tertuju untuk mencapai tujuan organisasi sebagai mental yang pro dan positif terhadap situasi kerja itulah yang akan mampu untuk memotivasi kerjanya untuk mencapai kinerja yang maksimal. Minat merupakan aspek penting dari kepribadian, merupakan kekuatan alamiah dari kepribadian itu sendiri. Minat merupakan momen dari kecenderungan-kecenderungan yang terarah secara intensif kepada satu obyek yang dianggap penting. Pada minat ini selalu terdapat elemen-elemen afektif (perasaan, emosional) yang kuat. Dalam konteks inilah Motivasi Kerja memiliki pengaruh yang kuat terhadap Kinerja Pegawai, sebagaimana temuan dalam penelitian tesis ini.

\section{Pengaruh Gaya Kepemimpinan $\left(X_{1}\right)$, terhadap Motivasi Kerja $\left(X_{2}\right)$}

Gaya Kepemimpinan berpengaruh langsung terhadap motivasi kerja dan juga berpengaruh tidak langsung terhadap Kinerja Pegawai melalui Motivasi Kerja secara sangat signifikan dengan koefisien jalur $=0,504$. Koefisien jalur pengaruh tidak langsung Gaya Kepemimpinan terhadap Kinerja Pegawai sebesar 0,504 ternyata lebih besar daripada koefisien jalur pengaruh langsungnya terhadap Kinerja Pegawai yaitu 0,483. Dengan demikian sesungguhnya antara Gaya Kepemimpinan dengan Kinerja Pegawai secara nyata terdapat pengaruh tidak langsung, atau pengaruh yang sebenarnya adalah pengaruh tidak langsung. Menurut hasil riset kepemimpinan pada perilaku kepemimpinan pada Universitas Michigan terdapat dua dimensi perilaku kepemimpinan yang disebut dengan gaya kepemimpinan berorientasi pada karyawan dan berorientasi pada produksi (tugas).

Gaya kepemimpinan berorientasi pada karyawan adalah pimpinan cenderung menekankan hubungan antar pribadi, memperhatikan kebutuhan manusiawi para karyawan, bisa mengerti perbedaan-perbedaan sifat yang dimiliki oleh karyawannya. Pemimpin selalu berusaha untuk menciptakan komunikasi dua arah dan suasana yang menyenangkan, serta selalu mengupayakan diri terhadap orang yang dipimpinnya. 
Harmonisasi hubungan yang tercipta merupakan media untuk penyampaian gagasan atau ide-ide yang perlu mendapat dukungan bersama. Pimpinan seperti ini berusaha membina kerja tim dan membantu para pegawai untuk menanggulangi masalah mereka. Gaya kepemimpinan berorientasi pada produksi atau tugas, cenderung menekankan aspek teknis atau tugas dari pekerjaan, perhatian utamanya adalah bagaimana menyelesaikan pekerjaan, membuat orang selalu sibuk dan mendesak anak buah untuk selalu berproduksi. Pemimpin yang berorientasi pada tugas cenderung memusatkan perhatian kepada organisasi, seperti memberikan rincian tentang tugastugas yang harus dilaksanakan, kapan dilaksanakan dan bagaimana melaksanakannya serta tidak mau mengerti kesulitan-kesulitan yang dialami oleh bawahan dalam menyelesaikan pekerjaan. Deskripsi di atas meyakinkan sebuah pernyataan implisit bahwa gaya kepemimpinan sangat erat kaitan dan kontribusinya kepada dorongan atau motivasi kerja pegawai. Pada akhirnya hal tersebut secara tidak langsung berpengaruh kepada Kinerja Pegawai, sebagaimana temuan dalam penelitian tesis ini.

\section{KESIMPULAN DAN SARAN}

Kesimpulan. (1) Gaya Kepemimpinan berpengaruh langsung positif terhadap Kinerja Pegawai, (2) Motivasi Kerja berpengaruh langsung positif terhadap Kinerja Pegawai. (3) Gaya Kepemimpinan berpengaruh lansung positif terhadap Motivasi Kerja dan secara tidak langsung berpengaruh terhadap Kinerja Pegawai.

Saran. Melalui penelitian ini, saran untuk kemajuan kinerja pegawai pada umumnya dan peningkatan Kinerja Pegawai Disbintalad sebagai berikut :

1. Terhadap unsur pimpinan disarankan sebagai berikut: (1) Menerapkan gaya kepemimpinan situasional yang disesuaikan dengan situasi dan kondisi satuan, (2) Menerapkan sebelas azaz kepemimpinan secara konsisten dan konsekuen, (3) Menerapkan sifat keperwiraan dan kesatriaan yang meliputi jujur, adil, peduli keterbukaan dan bertanggung jawab, (4) Menerapkan kepemimpinan lapangan dengan motto; Look at me, Tray with me dan Follow me.

2. Dalam rangka pengembangan Motivasi Kerja pegawai, dapat dilakukan hal-hal sebagai berikut: (1) Pimpinan Disbintalad selalu mendorong pegawainya untuk meningkatkan semangat kerja dengan upaya-upaya konkret dan proporsional serta memberikan perhatian terhadap kesejahteraannya melalui berbagai kesempatan dan sarana yang ada, (2) Pegawai Disbintalad secara sadar mau untuk terus belajar meningkatkan profesionalisme kinerjanya. Hal itu dapat dilakukan bila pegawai yang bersangkutan memiliki dorongan semangat bekerja yang baik dan kesadaran bahwa profesinya sebagai pegawai adalah profesi yang up-gradeable, yang terusmenerus harus diperbaharui dan dikembangkan mengikuti dinamika kerja, Sehingga melalui Motivasi Kerja, kinerja pegawai dapat ditingkatkan sesuai dengan tupoksinya. 


\section{DAFTAR RUJUKAN}

Chuck, Williams. Management. Texas: Texas Christian University, Thomson SouthWestern, 3rd edition, 2005.

Colquitt, Jason A.; Jeffery A. LePine \& Michael J. Wesson, Organizational Behavior: Improving Performance and Commitment in the Workplace. New York: McGraw Hill, 2009.

Daft, Richard L. Management. Jakarta: Salemba Empat, 2006.

Dessler, Gery. Management, Leading People and Organization the 21 st Century. Upper Saddle River New Jersey: Prentice Hall Inc., 2001.

George, Jennifer M. and Gareth R. Jones, Organizational Behavior, Third Edition. Upper Saddle River, New Jersey: Pearson Education, Inc., 2002.

Gibson, James L., et al, Organizations - Behavior, Structure, Processes. New Jersey: McGraw-Hill, Irwin, International Edition, 2006.

Ivancevich et al, Organizational Behavior and Management, $8^{\text {th }}$ Edition. New York: McGraw Hill, International Edition, 2008.

Kreitner, Robert; dan Angelo Kinicki. Perilaku Organisasi. Jakarta: Salemba Empat, Jakarta, 2005.

Mangkunegara, A.A. Anwar Prabu. Evaluasi Kinerja SDM. Bandung: PT. Refika Aditama, Cetakan Keempat, 2009.

McShane, Steven L.; and Mary Ann Von Glinow. Organizational Behavior-Emer-ging Realities for the Workplace Revolution. New Jersey: McGraw-Hill, Irwin, 2005.

Robbins Stephen P.; Timothy A. Judge. Organization Behavior. New Jersey: Pearson Education Inc., 2009.

Robbins, Stephen P. Essentials of Organizational Behavior, Seventh Edition. Upper Saddle River, New Jersey: Pearson Education, Inc., 2003.

Timpe, A. Dale et all. Seri Manajemen Sumber Daya Manusia: Kepemimpinan, alihbahasa: Susanto Budhidarmo. Jakarta: PT. Gramedia, 2002.

Gramedia, 2002.

Wibowo. Manajemen Kinerja. Jakarta: RajaGrafindo Persada, 2009.

Yukl, Gary. Leadership and Organization, Seventh Edition. Upper Saddle River, New Jersey: Pearson Education Inc., 2010. 
